\title{
THE INFLUENCE OF SERVICE QUALITY ON IRANIAN STUDENTS' SATISFACTION, LOYALTY AND WOM: A CASE STUDY OF NORTH CYPRUS
}

\author{
DOI: 10.17261/Pressacademia.2019.1031 \\ JMML- V.6-ISS.1-2019(3)-p.21-34
}

Naser Elahinia ${ }^{1}$, Mohammad Karami ${ }^{2}$

${ }^{1}$ Eastern Mediterranean University, Department of Business Administration, Faculty of Business and Economics, Cyprus. Naserelahinia@gmail.com, ORCID ID: 0000-0002-7280-8872

2 Eastern Mediterranean University, Department of Business Administration, Faculty of Business and Economics, Cyprus. Mohammad.karami6990@gmail.com, ORCID ID: 0000-0003-1903-828X

Date Received: January 16, 2018

Date Accepted: March 15, 2019

To cite this document

Elahinia, N., Karami, M. (2019). The influence of service quality on Iranian students' satisfaction, loyalty and WOM: A case study of north Cyprus. Journal of Management, Marketing and Logistics (JMML), V.6(1), p.21-34.

Permemant link to this document: http://doi.org/10.17261/Pressacademia.2019.1031

Copyright: Published by PressAcademia and limited licenced re-use rights only.

\begin{abstract}
Purpose - This study aims to investigate the relationship between SERVQUAL dimensions, students' satisfaction and post-satisfaction behaviors i.e. loyalty and word of mouth communıcatıon (WOM) in higher education in North Cyprus. For this purpose, a self-administrated survey carried out with the sample of 324 Iranian students in Eastern Mediterranean University, the biggest university in North Cyprus.

Methodology - The different dimensions such as reliability, tangibility, assurance, responsiveness and empathy have been taken as determinants of service quality. The reliability of service quality items, student satisfaction, loyalty and WOM has been investigated by Cronbach's Alpha test. T-test, Pearson correlation and linear regression model are used to examine the relationship between each individual variable in this study.

Findings - The findings highlighted that the dimensions of service quality are significantly related with students' satisfaction. Also, the results proved a positive relationship between students' satisfaction, loyalty and WOM.

Conclusion - Research stated that if an institution frequently offers service at levels that surpass the expectations of the student, such services will be appraised as being of high quality. On the other hand, if an institution continually falls short at meeting the expectations of students, the services will be regarded as being of poor quality. These finding have useful implications to higher education organizations particularly to international universities.
\end{abstract}

Keywords: SERVQUAL, loyalty, student satisfaction, higher education, word of mouth communication. JEL Classification: 123, M3, D83

\section{INTRODUCTION}

Education is an important and worthwhile investment that keeps yielding returns in many ways. A system of education that is robust and effective in several ways, results in better performance of students. Educational institutions with an effective system and administration that offer excellent services will continually have an influx of students.

In recent years massive changes in policy, structure and status of higher education institutions have taken place all over the world. Issues such as globalization, privatization and increased competition among higher learning institutions are now common in most countries (Damme, 2001; O'Neil \& Palmer, 2004).

Hill (1995), states that higher education is a service industry and that service quality is a critical determinant of the success of higher learning institutions (Landrum, Prybutok \& Zhang, 2007). In order to succeed in today's competitive higher education sector, service quality is of essence to any institution of higher learning (Sandhu \& Bala, 2011).

In view of this, higher education institutions must assess the quality of their services since outstanding service quality can provide them with competitive advantage. If the higher education institutions provide quality service which meet or exceed that expectations of their students, their services will be evaluated as high quality service and if not, the services will be judged as poor (Albrecht, 1991). 
Student satisfaction is a major challenge for higher education institutions and as Arambewela and Hall (2009) posit, it is also the major source of competitive advantage and the student satisfaction leads to student attraction, retention and the spread of positive word of mouth communication by satisfied students. Abdullah (2006) states that higher education institutions have to incorporate student satisfaction as an important component of their management in addition to their core business of teaching and research. Therefore, students are not seen as participants in the process of higher education but as customers or consumers of the process.

\section{LITERATURE REVIEW}

\subsection{Service Quality}

Definitions of quality of service focus on the idea that it should be decided according to the users' evaluation. Based on literature, quality has been conceptualized based on what is perceived by the user, hence the term perceived quality. The judgment of the user/customer of the general superiority of, or the experience of an entity has been described as perceived quality (Zammuto, Keaveney \& O'Connor, 1996). In the same way, Parasuraman, Zeithaml and Berry (1990) similarly established that the perception of quality of service by customers arises from likening the expectations before experiencing the service to their real service experience. Perceived quality has also been comprehended as a kind of attitude in association with but not exactly like satisfaction, deduced from an assessment of what one expects against what's ones' opinion of performance (Rowley, 1996).

Parasuraman, Zeithaml and Berry (1985) identified the factors contributing to excellent service quality that are generally applicable to service of different kinds. The dimensions are reliability, tangibility, competence, security, understanding responsiveness, access, communication, credibility and courtesy. Furthermore, the aforementioned dimensions have been rearranged into the recognized dimensions in the model of SERVQUAL (Parasuraman, Zeithaml \& Berry, 1990) which consists of reliability, assurance, responsiveness, tangibility and empathy.

- Tangibles: These are the physical amenities, tools and personnel guises.

- Reliability: This is the capability to carry out the service promised reliably and correctly.

- Responsiveness: This is the readiness and enthusiasm to support and deliver services quickly.

- Assurance: This is the understanding of service to be rendered and their ability to convey trust and confidence, as well as their courteousness in the process of service delivery.

- Empathy: This is the dimension of being concerned, giving personalized care to customers.

It is true that typical service-providing organizations and the institutions of higher education are not the same in terms of their unique features. Shostack (1977) stressed the significance of the intangible dimensions in the total delivery of services. One of the very intangible services is teaching. Soutar and McNeil (1996) stated that few attempts have been made to tie teaching to quality assurance, which is very significant in the service industry from the perspectives of students. The principles of marketing suggesting that the strategy of institutions of higher education ought to stem from the needs of the student, have not been considered much in the discourse centred around accountability in higher institutions of learning.

\subsection{Student Satisfaction}

Satisfaction has been described by Kotler and Clarke (1987) as a fulfilment arising from someone's experience of an outcome or a performance that satisfies the expectation he/she has. Satisfaction depends on the expectation level of the customer and the performance that has been perceived. However the expectations of students in the university could go as far as prior to the time the students enrolled and even before they enrolled at the institution (Palacio, Meneses and Perez, 2002), it has been argued that student satisfaction only involves matters of the perception of students and the experiences they have in the institution during their studies (Carey, Cambiano \& De Vore, 2002; Hasan, Ilias, Rahman \& Razak, 2009).

Navarro, Iglesias and Torres (2005)stated that, the qualities of the institutions are appraised by the students based on reliability, tangibility, and responsiveness as well as management of the organization. These different aspects directly impact student satisfaction. The quality of faculty members, academic reputation of the institution and availability of amenities are significant although, market orientation is known as a more critical standard of satisfaction for students (Mavondo, Zaman \& Abubakar, 2000).

\subsection{Word of Mouth Communication}

Word of Mouth (WOM) has been described as the spoken communication from person-to-person, among groups like independent experts, friends and family lacking commercial objective to obtain improved services (Lampert \& Rosenberg, 
1975). Studies have reported that WOM impacts decisions of students and it is because WOM is believed to be a more reliable source of information compared to other channels of communication (Chang, Lee \& Huang, 2010).

The content of WOM might be very inconstant in volume and valence; it may occur rarely or often, and it may also be negative communication or positive communication (Walker, 2001). Satisfied students can share their experience in form of positive WOM with about four or five persons, and dissatisfied students will share their bad experiences with over 9 persons (Cengiz \& Yayla, 2007).

Word of Mouth Communication is effective in keeping customers and attracting new ones through customers that have been previously satisfied (Haywood, 1989). One of the defining factors for service providers and consumers to give positive WOM in the phase of post-consumption is service satisfaction (Patti \& Chen, 2009). Researchers state that high student satisfaction results in positive WOM and higher buying intentions (File, Cermak \& Prince, 1994; Wirtz \& Chew, 2002). Consumers will possibly spread negative WOM when service quality falls below the expected standard. They can do this by directly contacting potential students, particularly those with strong social bonds with the students, with the aim of preventing the terrible customer experiences from reoccurring (Walker, 2001; Wirtz \& Chew, 2002). In addition, WOM sources, who are often in proximity to students, are the main influencers and they should be counted in WOM promotion as part of the target audience (Lau \& Ng, 2001).

\subsection{Student Loyalty}

Loyalty has been described as a sincerely held obligation to repurchase a chosen service or product constantly in future, in spite of circumstantial impacts and marketing forces' ability to warrant switching behavior (Back, 2005).

In higher education industry's context, Helgesen and Nesset (2007) submitted that the loyalty of students comprises of not only the timeframe of which a student is registered at the institution of higher education but also after the completion of the students' program. Based on the importance of keeping currently registered students for institutions' development, the objective of the institutions of higher education is to urge their students to remain loyal while registered in their present courses and to choose to study further at the same institution as well (Goolamally \& Latif, 2014).

Previous researchers have found the links (direct and indirect) between perceptions of the quality of service by the student and their loyalty (Helgesen \& Nesset, 2007; Mendez, Parraga, Kara \& Urrutia, 2009). The conceptual framework identifies a direct connection existing between loyalty and service quality.

\section{HYPOTHESIS DEVELOPEMENT}

\subsection{Service Quality and Student Satisfaction}

Parasuraman, Ziethmal and Berry (1994) argued that service quality is one of the principles of student satisfaction. Same authors (1988) combined service quality with satisfaction. They described service quality as form of view that is a long term overall assessment, while satisfaction as a measurement criterion. Based on such definition, it is intended that perceived service quality is a worldwide measure and so, the direction of causality was from satisfaction to service quality (Parasuraman et al, 1988). Parasuraman, Zeithmal and Berry (1991) considered that reliability was fundamentally related to the outcome of service while tangibles, empathy, assurance and responsiveness were considered a process of service delivery. The issues not only judge the accuracy and reliability (i.e. dependability) of the service, but they also ascertain to the other service factors that are being prepared.

Therefore, student satisfaction can be related not only to the judgment of student about the reliability of the service prepared but to the experience of students of service delivery progress as well. The students will determine service quality not as positive if perceptions are less than expectation, and positively if these perceptions are higher. If service quality can be defined as the difference between perceptions and expectations, it will be essential to consider both of them. Service quality is conducted to exceed student expectations, for this reason we suggest following hypothesis:

H1: Service quality has positive effect on student satisfaction.

\subsection{Student Satisfaction and WOM}

WOM communication is a form of student satisfaction feedback as well as a type of ultimate assessment of quality perception (Smoldt, 1998; Bowman \& Narayandas, 2001; Gittell, 2002). It could be argued that, the satisfaction of students with a perceived quality of service offered will result in WOM (Athanassopoulos, Gounaris \& Stathakopoulos, 2001).

Sundaram, Mitra and Webster (1998) stated that based on the empirical investigation, the satisfaction of students will really influence repurchasing behaviours, positive WOM and loyalty. The more satisfied a student is, the more positive the WOM effect the student will spread (Mangold 1999). Usually, a number of authors have identified that satisfaction results in a higher likelihood that positive things will be spread by students about an institution and that the university will be 
mentioned to another prospective student In general, it would be argued that satisfaction of students could be an active promoter of the institution's services and products (Bettencourt, 1997; Dolen, Dabholkar \& De Ruyter, 2007).

Many scholars found a positive association between WOM and satisfaction (e.g. Oliver \& Swan, 1989), though some other empirical investigations found a negative correlation between them, as a result of dissatisfied students being more actively engaged in word-of-mouth than satisfied students (Bearden \& Teel, 1983; Richins, 1983). Marketers, especially those of services, have since discussed the significance of positive WOM as an element highly impacting student service choice and service usage.

Word-of-mouth has been understood to possess persuasive and influential efficiency and a substantial effect on the choices of students (Richins, 1983) as well as on perceptions of the product or service after the purchase (Bone, 1995). As indicated by Gremler, Bitner and Evans (1994), on many occasions, word-of-mouth seems to be the main basis of information used by students. Therefore, the following hypothesis is developed:

H2: Students' Satisfaction has significant effect on WOM.

\subsection{Student Satisfaction and Loyalty}

As mentioned earlier, students' satisfaction is the function of the comparative expectations level and performance perceived, whereas loyalty reveals a satisfactory attitude towards the institution (Evanschitzky, Lyer, Plassmann, Niessing, Meffert, 2006; Dick \& Basu, 1994). Based on this institutions in higher education provide satisfaction to students /clients with the hopes of gaining the loyalty of their students (Oliver, 1999).

According to McDougall and Levesque (2000), students who are satisfied develop "loyalty intentions" which means the disposition to carry on their study in the institution and this should be the principal concern of the institution. Nonetheless, Gounaris and Stathakopoulos (2004) stated that, loyalty that is covetous hardly includes purchasing behavior and hence there are two loyalty types that directly impact the institution's financial and market standings. The connection between loyalty and satisfaction is not very clear (Oliver, 1999). For example, social forces have been said to aid the achievement of the successful conversion of satisfaction into loyalty.

Based on the conceptual variance between inertia and premium loyalty, satisfaction relates with the growth of the latter for the reason that it grows because of satisfactory service encounter that helps develop a favorable attitude to the institution and educational embracement of the choice of the student. Conversely, recurring purchases owing to habits or convenience (that is inertia loyalty) could be unconnected to satisfaction (Oliver, 1999). Based on these, the following hypothesis is examined:

H3: Student satisfaction has positive effect on loyalty.

\subsection{Loyalty and WOM}

Loyalty reflects great state of mind toward the organization. Thus, recommendation and positive WOM are viewpoints related to loyalty (Hallowell, 1996). Specifically, loyal students usually advance the university by placing emphasis on the most relevant service features. With this, a higher value is derived. It motivates one to remain loyal to the university hence, promoting via positive WOM acts.

Jones and Sasser (1995) accepted that loyal students will exhibit certain loyal attributes such as giving service recommendations, presenting unused understudies to a university. In the event that a university needs to fortify its WOM impact, improving understudy loyalty is primary. Certain passions are evident between a university and a loyal student, and such student will relay a positive encounter with regards to utilizing the products or services to anyone demanding information about the college (Reichheld \& Sasser, 1990; Ranaweera \& Prabhu, 2003). In case a student trusts the service of an institution, such student will communicate positively about the institution with other people (Li, 2013). Based on the argument presented above, the following hypothesis is suggested:

H4: Loyalty has positive effect on WOM.

Based on the above literature reviews the following model shown in Figure 1, has been proposed based on the majority results of previous studies. 
Figure 1: Theoretical Model of Study

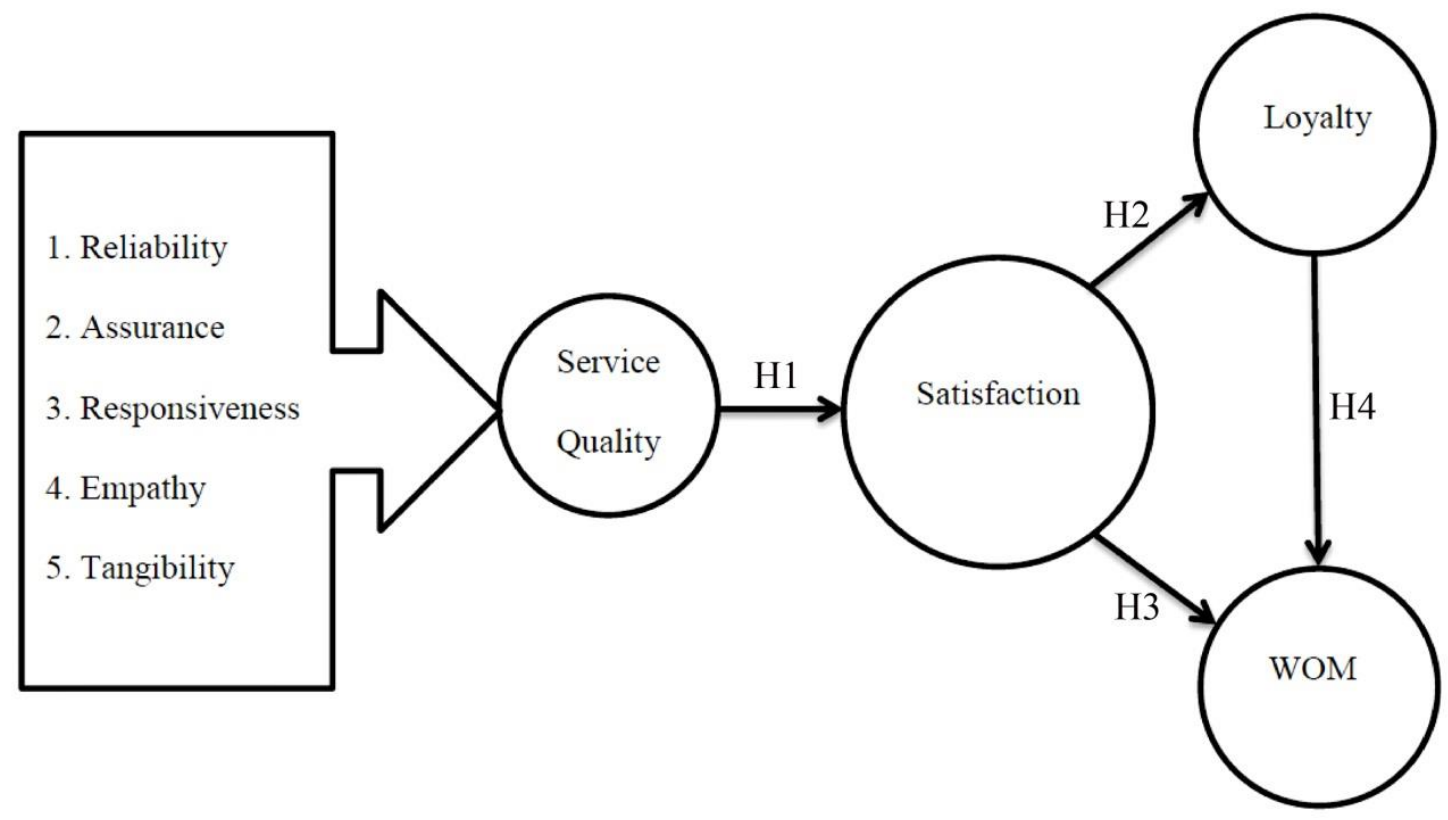

\section{DATA AND METHODOLOGY}

\subsection{Sample and Data Collection}

The quantitative approach was employed to adequately analyze the model proposed. In line with this, a research model is conceptualized based on a theoretical framework. This current study's research model was drawn and constructed using SERVQUAL model (Parasuraman, Ziethmal \& Berry, 1990). The data for this study were collected through a selfadministered survey questionnaire. The survey questionnaire technique was chosen due to the advantages it offers, such as the respondents' control of time, low cost, no geographical boundary, no bias of interviewer, and secrecy in responses (Bahadur, Aziz \& Zulfiqar, 2018). Data were collected from Iranian student population in different faculties; their total number is about 1600, according to the Iranian Students Association in North Cyprus. In total, 400 questionnaires were distributed by the researcher and 324 questionnaires were completed (the response rate is $81 \%$ ). In order to ascertain if the questions used were clearly understood by the respondents, a pilot study was hence conducted. This consisted of a total of 10 students from Faculty of Business, Pharmacy and other faculties. Participants were briefed about the objective of this study before questionnaires were distributed. It was realized that there were no ambiguity in the questions as respondents had no problems understanding them. However, some comments were helpful in improving the questionnaire.

\subsection{Measurements}

The measurement items scale came from previous literature, adapted to fit the service setting. Previous research exploring relationships among perceived service quality, customer satisfaction, loyalty, and WOM have typically relied on a survey method (Cronin \& Taylor, 1992; Bettencourt, 1997; Gronholdt, Martensen \& Kristensen, 2000; Walker, 2001). In the present study as well, the survey method was used .

Data were collected via structured questionnaire consisting of four sections; SERVQUAL dimensions (reliability, assurance, responsiveness, empathy and tangibility), students' satisfaction, loyalty and word of mouth communication (De Oliveira \& Ferreira, 2009). Although some slight changes were made to the order of sections, the content remained original (See Appendix).

For the content validity of questionnaires, Likert-type scale was used to show the respondent preference on each item. Likert-type scales were used because research has indicated that they are easily completed by respondents (Matell \& Jacoby, 1972) and provide reliable data (Lissitz \& Green, 1975). Students were asked to indicate their responses on a fivepoint Likert-type scale which are represented by numbers $1=$ Very Dissatisfied, $2=$ Dissatisfied, $3=$ Neutral, $4=$ Satisfied and 5 = Very Satisfied (Vagias, 2006; Dawes, 2008). Cronbach's alpha was employed to confirm the variables' reliability. It should be noted that the cutoff level for the alpha coefficient commonly accepted is 0.7 . In addition, to test the hypotheses, $T$ test, correlation and regression analyses have been conducted. 


\section{DATA ANALYSIS AND RESULTS}

The analysis was conducted using 324 questionnaires. The frequency of the different categories of students was examined to create a respondents' profile. Standard deviations and mean of variables were estimated to provide a proper descriptive analysis. Subsequently, using IBM SPSS, the composite scores of the various variables' items were calculated in order to conduct T-test, correlation and regression analyses.

\subsection{Sample}

Respondent's detail section asked demographic questions such as gender, age, degree program, and faculty of study. A demographic analysis of this sample is presented in Table 1. More than half of the respondents were male i.e. $57.4 \%$ and $42.6 \%$ female. As reported in Table 1, 58.1\% of the respondents were aged between $25 y e a r s$ and below; $20.7 \%$ of the respondents were in the age group 26-30 while the others were older than 31 . Sixty-eight percent of the respondents were bachelors' students who were studying in the 5- year program which is composed of 10 semesters (Pharm.D), while 23.5\% of respondents were master students and rest of them were PhD students. Forty-one percent of them were from the Faculty of Pharmacy, $16.7 \%$ of respondents were from the Faculty of Business and Economics, $11.4 \%$ percent belonged to the Faculty of Medicine and the rest were from other faculties.

Table 1: Profile of Respondents $(n=324)$

\begin{tabular}{|c|c|c|}
\hline & Frequency & Percent \\
\hline \multicolumn{3}{|l|}{ Age } \\
\hline 20 and Below & 41 & 12.7 \\
\hline $21-25$ & 147 & 45.4 \\
\hline $26-30$ & 67 & 20.7 \\
\hline $31-35$ & 55 & 17.0 \\
\hline 36 and $A B$ & 14 & 4.3 \\
\hline Total & 324 & 100.0 \\
\hline \multicolumn{3}{|l|}{ Gender } \\
\hline Male & 186 & 57.4 \\
\hline Female & 138 & 42.6 \\
\hline Total & 324 & 100.0 \\
\hline \multicolumn{3}{|l|}{ Degree programmed } \\
\hline Bachelor's & 222 & 68.5 \\
\hline Master's & 76 & 23.5 \\
\hline Doctoral & 26 & 8.0 \\
\hline Total & 324 & 100.0 \\
\hline \multicolumn{3}{|l|}{ Faculty } \\
\hline Architecture & 20 & 6.2 \\
\hline Art and Sciences & 7 & 2.2 \\
\hline Business and Economic & 54 & 16.7 \\
\hline Communication and Media Studies & 4 & 1.2 \\
\hline Tourism & 17 & 5.2 \\
\hline Medicine & 37 & 11.4 \\
\hline Health Sciences & 13 & 4.0 \\
\hline Pharmacy & 132 & 40.7 \\
\hline Engineering & 31 & 9.6 \\
\hline Law & 3 & .9 \\
\hline Education & 6 & 1.9 \\
\hline Total & 324 & 100.0 \\
\hline
\end{tabular}

\subsection{Reliability Test}

As can be seen in the table below, all Alpha coefficients are above 0.7 and much close to 0.9 , which means that all variables are reliable. The results indicate that the scale had high internal stability. 
Table 2: Reliability Test Results

\begin{tabular}{lllll}
\hline No. & Variables & No. of Items & $\begin{array}{l}\text { Corrected } \\
\text { Correlation }\end{array}$ & $\begin{array}{l}\text { Item-Total } \\
\text { Cronbach's Alpha if Item } \\
\text { Deleted }\end{array}$ \\
\hline 1 & Tangibility & 5 & 0.581 & 0.902 \\
2 & Assurance & 4 & 0.663 & 0.897 \\
3 & Reliability & 4 & 0.709 & 0.893 \\
4 & Responsiveness & 4 & 0.683 & 0.895 \\
5 & Empathy & 2 & 0.659 & 0.898 \\
6 & Overall service quality & 19 & 0.942 & 0.882 \\
7 & Student Satisfaction & 5 & 0.766 & 0.889 \\
8 & Loyalty & 2 & 0.520 & 0.909 \\
9 & WOM & 5 & 0.725 & 0.892 \\
\hline
\end{tabular}

\subsection{Correlation Results}

The correlation matrix, standard deviation and means of variables have been shown in Table 3. Based on results, the mean score for each variable in the study revealed that, overall quality came highest ( 3.2471 with SD $=.63835$ ), followed by WOM (3.1488), student satisfaction (3.1432) and loyalty with the lowest score $(3.0154 \mathrm{SD}=0.96281)$

According to table, the correlations results between all variables were significant; showing that satisfaction $(r=0.693)$ is significantly associated with the overall quality, tangibility $(r=0.461)$, assurance $(r=0.549)$, reliability $(r=0.561)$, responsiveness $(r=0.507)$, empathy $(r=.586)$ as well as with loyalty $(r=0.572)$ and WOM $(r=0.707)$. In fact, all of the coefficients were positively significant at $1 \%$ confidence level. While this relationship has a great strength of half in the WOM, overall quality and then empathy with satisfaction, the correlation among loyalty, assurance, reliability and responsiveness with satisfaction shows a medium power. Therefore, the results revealed that the strongest relationship is between students' satisfaction and WOM (0.707) and the weakest is tangibility (0.461).

Table 3: Correlation, SD and Mean of Variables

\begin{tabular}{|c|c|c|c|c|c|c|c|c|c|c|c|c|}
\hline No. & Variables & 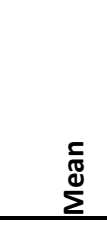 & 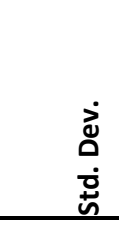 & 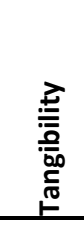 & 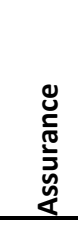 & 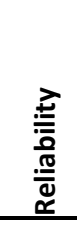 & 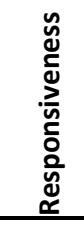 & 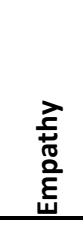 & $\tilde{n}$ & 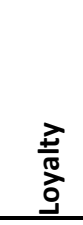 & $\begin{array}{l}\Sigma \\
ٍ \\
\vdots\end{array}$ & 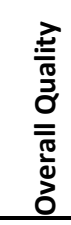 \\
\hline 1 & Tangibility & 3.2043 & .66722 & 1 & & & & & & & & \\
\hline 2 & Assurance & 3.3164 & .86414 & $\begin{array}{l}.469 \\
* *\end{array}$ & 1 & & & & & & & \\
\hline 3 & Reliability & 3.2477 & .80259 & $\begin{array}{l}.476 \\
* *\end{array}$ & $\begin{array}{l}.526 \\
* *\end{array}$ & 1 & & & & & & \\
\hline 4 & Responsiveness & 3.3066 & .84179 & $\begin{array}{l}.489 \\
* *\end{array}$ & $\begin{array}{l}.524 \\
* *\end{array}$ & $\begin{array}{l}.662 \\
* *\end{array}$ & 1 & & & & & \\
\hline 5 & Empathy & 3.1605 & .93794 & $\begin{array}{l}.405 \\
* *\end{array}$ & $\begin{array}{l}.460 \\
* *\end{array}$ & $\begin{array}{l}.492 \\
* *\end{array}$ & $\begin{array}{l}.496 \\
* *\end{array}$ & 1 & & & & \\
\hline 6 & SS & 3.1432 & .83276 & $\begin{array}{l}.461 \\
* *\end{array}$ & $\begin{array}{l}.549 \\
* *\end{array}$ & $\begin{array}{l}.561 \\
* *\end{array}$ & $\begin{array}{l}.507 \\
* *\end{array}$ & $\begin{array}{l}.586 \\
* *\end{array}$ & 1 & & & \\
\hline 7 & Loyalty & 3.0154 & .96281 & $\begin{array}{l}.271 \\
* *\end{array}$ & $\begin{array}{l}.349 \\
* *\end{array}$ & $\begin{array}{l}.351 \\
* *\end{array}$ & $\begin{array}{l}.267 \\
* *\end{array}$ & $\begin{array}{l}.425 \\
* * \\
\end{array}$ & $\begin{array}{l}.572 \\
* *\end{array}$ & 1 & & \\
\hline 8 & WOM & 3.1488 & .87735 & $\begin{array}{l}.425 \\
* *\end{array}$ & $\begin{array}{l}.510 \\
* *\end{array}$ & $\begin{array}{l}.534 \\
* *\end{array}$ & $\begin{array}{l}.529 \\
* *\end{array}$ & $\begin{array}{l}.489 \\
* *\end{array}$ & $\begin{array}{l}.707 \\
* *\end{array}$ & $\begin{array}{l}.578 \\
* *\end{array}$ & 1 & \\
\hline 9 & $\begin{array}{l}\text { Overall } \\
\text { Quality }\end{array}$ & 3.2471 & .63835 & $\begin{array}{l}.704 \\
* *\end{array}$ & $\begin{array}{l}.774 \\
* *\end{array}$ & $\begin{array}{l}.813 \\
* *\end{array}$ & $\begin{array}{l}.820 \\
* *\end{array}$ & $\begin{array}{l}.758 \\
* *\end{array}$ & $\begin{array}{l}.693 \\
* *\end{array}$ & $\begin{array}{l}.435 \\
* *\end{array}$ & $\begin{array}{l}.645 \\
* *\end{array}$ & 1 \\
\hline
\end{tabular}

Note: *Significant at $10 \%,{ }^{* *}$ Significant at $5 \%, * * *$ Significant at $1 \%$. 


\subsection{T-test Results}

According to the information presented in the Tables 4 and 5, it can be deduced that based on the value of $p$ less than 0.05 , $(p=0.036<.05)$ equal variances not assumed. So, Satisfaction with the quality of the service between two groups of male and female is not significant $(0.121>0.05)$.

Table 4: T test gender and Student Satisfaction

\begin{tabular}{llllll}
\hline & Gender & $\mathbf{N}$ & Mean & Std. Dev. & Std. Error Mean \\
\hline \multirow{2}{*}{ Student Satidfaction } & Male & 186 & 3.0828 & .88460 & .06486 \\
\cline { 2 - 5 } & Female & 138 & 3.2246 & .75279 & .06408 \\
\hline
\end{tabular}

Table 5: Independent Sample Test

\begin{tabular}{|c|c|c|c|c|c|c|c|c|c|c|}
\hline & & \multicolumn{2}{|c|}{$\begin{array}{l}\text { Levene's Test } \\
\text { for Equality } \\
\text { of Variances }\end{array}$} & \multicolumn{7}{|c|}{ T-test for Equality of Means } \\
\hline & & \multirow[b]{2}{*}{ 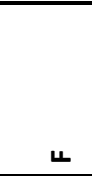 } & \multirow[b]{2}{*}{$\stackrel{000}{n}$} & \multirow[b]{2}{*}{+} & \multirow[b]{2}{*}{$\stackrel{4}{0}$} & \multirow{2}{*}{ 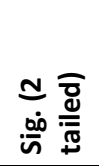 } & \multirow{2}{*}{ 离 } & \multirow{2}{*}{ 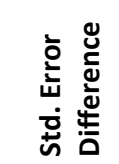 } & \multicolumn{2}{|c|}{$\begin{array}{l}\text { 95\% Confidence } \\
\text { Interval of the } \\
\text { Difference }\end{array}$} \\
\hline & & & & & & & & & Lower & Upper \\
\hline \multirow{2}{*}{$\begin{array}{l}\text { Student } \\
\text { Satisfaction }\end{array}$} & $\begin{array}{l}\text { Equal } \\
\text { variances } \\
\text { assumed }\end{array}$ & 4.430 & .036 & -1.519 & 322 & .130 & -.14184 & .09337 & -.32554 & .04185 \\
\hline & $\begin{array}{l}\text { Equal } \\
\text { variances } \\
\text { not } \\
\text { assumed }\end{array}$ & & & -1.556 & $\begin{array}{l}315.9 \\
3\end{array}$ & .121 & -.14184 & .09118 & -.32124 & .03755 \\
\hline
\end{tabular}

\subsection{Regression Results}

The results of regressions are shown in the Table 6 . As it can be seen, overall service quality positively influences student satisfaction in the positive way $(\beta=0.693, P<0.001)$ thus, hypothesis 1 is supported. The outcome depicts student satisfaction positively and significantly connects to loyalty $(\beta=0.572, p<0.001)$ which is in agreement with hypothesis 2 . The results also indicate there is significant positive association between student satisfaction and WOM thus, hypothesis 3 is supported $(\beta=0.707, p<0.001)$. Finally, the results revealed that loyalty has positive effect on WOM $(\beta=.578, p<.001)$ hypothesis 4 is supported.

\section{Table 6: Assessments of Regression Weights}

\begin{tabular}{|c|c|c|c|c|c|c|c|c|c|c|}
\hline \multicolumn{4}{|c|}{ Model } & \multirow[b]{2}{*}{ 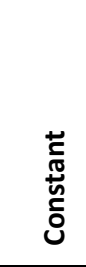 } & \multirow[b]{2}{*}{ نَّ } & \multirow[b]{2}{*}{ 芯 } & \multirow[b]{2}{*}{$\vdash$} & \multirow[b]{2}{*}{ 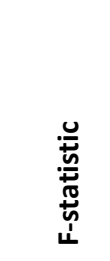 } & \multirow[b]{2}{*}{ 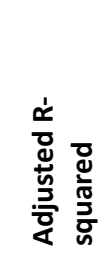 } & \multirow[b]{2}{*}{$\begin{array}{l}\frac{n}{5} \\
\stackrel{5}{3} \\
\stackrel{4}{x}\end{array}$} \\
\hline & INDEPENDENT & | & DEPENDENT & & & & & & & \\
\hline H1 & $\begin{array}{l}\text { Overall } \\
\text { quality }\end{array}$ & $\Rightarrow$ & Satisfaction & .210 & .052 & $.693 * * *$ & 17.226 & 296.72 & .480 & Supported \\
\hline $\mathrm{H} 2$ & Satisfaction & $\Rightarrow$ & loyalty & .937 & .053 & $.572 * * *$ & 12.507 & 156.42 & .327 & Supported \\
\hline H3 & Satisfaction & $\Rightarrow$ & WOM & .809 & .042 & $.707 * * *$ & 17.916 & 320.97 & .499 & Supported \\
\hline H4 & Loyalty & $\Rightarrow$ & WOM & 1.56 & .041 & $.578 * * *$ & 12.716 & 161.70 & .334 & Supported \\
\hline
\end{tabular}




\section{FINDINGS AND DISCUSSIONS}

\subsection{Evaluations of Findings}

The observation of this study was to test the impact of and relationship between service quality, student satisfaction, WOM and loyalty in the educational services section.

According to the findings, service quality positively affected student satisfaction. Perceived service quality is the entire assessment of a student upon receiving a service. Thus, the university should concentrate on ensuring they satisfy student prerequisites and advertise the reliability of their service to the students.

Based on finding, student satisfaction positively influenced student loyalty. Generally, loyalty of customers will result in the attitude of repurchasing a company's products or services. As Jones and Sasser (1995) argued, a satisfied customer with a service or product will normally increase his or her loyalty to the firm. The findings of the study show that a similar behavior could be seen in university loyalty too.

In regards to results related to the relationship between customer satisfaction and WOM, it was positive significant association. Athanassopoulos, Gounaris and Stathakopoulos (2001) maintained in their study that satisfaction of customers has a direct influence on WOM. However, it should be stated that, the difficulty in creating WOM for students in an institution is more than in a common service industry for clients.

As it can be seen from finding, customer loyalty had positive impact on WOM. WOM is related to the behavior of consumers in telling other people their brand experiences (Narayandas \& Bowman, 2001). WOM serves as an index of buyer satisfaction and loyalty in the investigation of the impact of loyalty in return for purchase and WOM (Gounaris \& Stathakopoulos, 2004). Researchers moreover affirmed that WOM was significantly influenced by behavioral brand loyalty (Hajli, Lin, Featherman, Wang, 2014).

\subsection{Theoretical Implications}

Results of this study further extended the current research on SERVQUAL dimensions (Parasuraman, Zeithaml \& Berry, 1990). As previously mentioned perceived service quality has five dimensions (Reliability, Assurance, Responsiveness, Empathy and Tangibility) and there might be the outcome of the appraisals of different service encounters. In higher education institutions, students can encounter with instructors, professors, departmental chairs and so on (Hill, 1995). Consequently, if an institution frequently offers service at levels that surpass the expectations of the student, such services will be appraised as being of high quality. On the other hand, if an institution continually falls short at meeting the expectations of students, the services will be regarded as being of poor quality.

Also, according to Kotler \& Clarke (1987), satisfaction depends on the difference between the services expected and the service that has been perceived in the actual performance of the service provider. The association between the quality of service dimensions and the satisfaction of students is explained in this research. Thus, this research contributes to the literature by demonstrating that overall service quality dimensions of the university related to student satisfaction and Behavior after purchasing.

Satisfied students have a great desire to continue the rest of their study at the previous institution (Oliver, 1999). They are also good advertisers for the university so that they can be well-forwarded to their friends and relatives and encourage them to come and study at this university.

\subsection{Managerial Implications}

Management of even top universities has to make substantial efforts to make sure their students share positive word-ofmouth about the institution. Non-private institutions of higher education hardly experience the difficulty of recruiting students when compared with their privately owned competitors especially in the period of lower birth-rates and population. Thus, privately owned institutions in higher education have to concentrate on high service quality dimensions (Li, 2013).

All faculty members and lecturers must be trained to treat students as customers to satisfy their psychological and studying needs. Nowadays, certainly, students are steadily changing roles from being just students to assuming student-customers position in private universities because of alternatives present in North Cyprus. The faculty members need to control their ego to better meet the needs of the students, not simply by teaching them but also by respecting and assisting them; provide a quick and satisfactory answer to their rational demands in the best possible way. Faculty members have to treat students as a part of their family so as to breed loyalty to the institution. As soon as students perceive a supporting system, then they will develop a sense of being a part of the organization. Students would like to respond promptly and effectively to their problems and questions, and treat them with a very honest and polite way in order to attract their trust and 
confidence; the university must fulfill its promises and commitments correctly. Modern equipment and physical evidence have an impact on increasing students' satisfaction from university services and should be taken into consideration.

The manager must have noticed that a modern and dynamic relationship is used before, during and after studying, to share useful education information and programs to undergraduates all the time for keeping and enrolling them. The university can also use the points of view and experience of graduates to develop and enhance the quality of services, and word-ofmouth will be certainly encouraged. That is a real operational means of recruiting new students by a university.

\section{CONCLUSION}

The current study used a model that examines the effect of five service quality dimensions (reliability, assurance, responsiveness, empathy and tangibility) on the satisfaction of students, loyalty as well as eventual WOM as free and easy advertising. For this purpose, 324 Iranian students at a university in North Cyprus (Eastern Mediterranean University) were chosen conveniently as participants, the study examined the quality of service and student satisfaction in the institution, in addition to its subsequent outcomes.

Examining these interactions is significant for four reasons; the main reason is, growing demand for a quality higher education. Second, in the current competition in the higher education sector students are faced with a lot of options offered. Third, the staffs of the university are not fully aware of the wishes and needs of the students, as well as the consequences of dissatisfaction. Fourth, due to the globalization of universities, the high cost of advertising and student attraction, it is necessary to give devotion to quality of service as well as behaviors after using services more than before. The last reason is that the trend of marketing traditional services to modern and word of mouth marketing is growing fast.

Results show that relationship between service quality dimensions were significantly and positively associated with loyalty and eventually WOM and student's satisfaction. The findings reveal that personalized attention with the institution's staff is really important to the students. Results also indicate that reliability of the university, the assistance to solve the student's problems and respectful encounter of the employees and lecturers are related to satisfaction, intention to either recommend the university to their friends and family or in their decision to pursue their studies to the higher degree of education. Although physical evidence has shown that the least relationship with student satisfaction, loyalty is significantly associated with WOM. This work reveals that the level of students' satisfaction with the education provided in EMU mirrors the quality of method and offered services provided in EMU. Furthermore, the loyalty and WOM as potential behaviors of student were examined along with their effectiveness and impact in this research. Factors considered in the current study evidently explain the correlation between quality of service, the satisfaction of students, loyalty as well as the WOM.

\section{REFERENCES}

Abdullah, F. (2006). Measuring service quality in higher education: HEdPERF versus SERVPERF. Marketing Intelligence \& Planning, 24(1), 3147.

Albrecht, K. M. (1991). Quality criteria for school-age child care programs. Project Home Safe.

Arambewela, R., Hall, J. (2009). An empirical model of international student satisfaction. Asia Pacific journal of marketing and logistics, 21(4), 555-569.

Athanassopoulos, A., Gounaris, S., Stathakopoulos, V. (2001). Behavioural responses to customer satisfaction: an empirical study. European journal of marketing, 35(5/6), 687-707.

Back, K. J. (2005). The effects of image congruence on customers' brand loyalty in the upper middle-class hotel industry. Journal of Hospitality \& Tourism Research, 29(4), 448-467.

Bahadur, W., Aziz, S., Zulfiqar, S. (2018). Effect of employee empathy on customer satisfaction and loyalty during employee-customer interactions: The mediating role of customer affective commitment and perceived service quality. Cogent Business \& Management, 5(1), 121.

Bearden, W. O., Teel, J. E. (1983). Selected determinants of consumer satisfaction and complaint reports. Journal of marketing Research, 21-28.

Beerli Palacio, A., Díaz Meneses, G., Pérez Pérez, P. J. (2002). The configuration of the university image and its relationship with the satisfaction of students. Journal of Educational administration, 40(5), 486-505.

Berry, L. L., Zeithaml, V. A., Parasuraman, A. (1990). Five imperatives for improving service quality. MIT Sloan Management Review, 31(4), 29

Bettencourt, L. A. (1997). Customer voluntary performance: Customers as partners in service delivery. Journal of retailing, $73(3), 383$.

Bone, P. F. (1995). Word-of-mouth effects on short-term and long-term product judgments. Journal of business research, 32(3), $213-223$.

DOI: 10.17261/Pressacademia.2019.1031 
Bowman, D., Narayandas, D. (2001). Managing customer-initiated contacts with manufacturers: The impact on share of category requirements and word-of-mouth behavior. Journal of marketing Research, 38(3), 281-297.

Carey, K., Cambiano, R. L., De Vore, J. B. (2002). Student to faculty satisfaction at a Midwestern university in the United States. In The 25th HERSDA Annual Conference.

Cengiz, E., Yayla, H. E. (2007). The effect of marketing mix on positive word of mouth communication: Evidence from accounting offices in Turkey. Innovative Marketing, 3(4), 73-86.

Chang, L. Y., Lee, Y. J., Huang, C. L. (2010). The influence of e-word-of-mouth on the consumer's purchase decision: A case of body care products. Journal of Global Business Management, 6(2), 1.

Cronin Jr, J. J., Taylor, S. A. (1992). Measuring service quality: a reexamination and extension. The journal of marketing, 55-68.

Dawes, J. (2008). Do data characteristics change according to the number of scale points used? An experiment using 5-point, 7-point and 10-point scales. International journal of market research, 50(1), 61-104.

De Oliveira, O. J., Ferreira, E. C. (2009, May). Adaptation and application of the SERVQUAL scale in higher education. In Proceedings of POMS 20th Annual Conference Orlando, Florida USA.

Dick, A. S., Basu, K. (1994). Customer loyalty: toward an integrated conceptual framework. Journal of the academy of marketing science, 22(2), 99-113.

Evanschitzky, H., Iyer, G. R., Plassmann, H., Niessing, J., Meffert, H. (2006). The relative strength of affective commitment in securing loyalty in service relationships. Journal of Business Research, 59(12), 1207-1213.

Gittell, J. H. (2002). Relationships between service providers and their impact on customers. Journal of Service Research, 4(4), $299-311$.

Goolamally, N., Latif, L. A. (2014). Determinants of student loyalty in an open distance learning institution. In Seminar Kebangsaan Pembelajaran Sepanjang Hayat (pp. 390-400).

Gounaris, S., Stathakopoulos, V. (2004). Antecedents and consequences of brand loyalty: An empirical study. Journal of brand Management, 11(4), 283-306.

Gremler, D. D., Jo Bitner, M., Evans, K. R. (1994). The internal service encounter. International Journal of Service Industry Management, 5(2), 34-56.

Gronholdt, L., Martensen, A., Kristensen, K. (2000). The relationship between customer satisfaction and loyalty: cross-industry differences. Total quality management, 11(4-6), 509-514.

Hajli, N., Lin, X., Featherman, M., \& Wang, Y. (2014). Social word of mouth: How trust develops in the market. International Journal of Market Research, 56(5), 673-689.

Hallowell, R. (1996). The relationships of customer satisfaction, customer loyalty, and profitability: an empirical study. International journal of service industry management, 7(4), 27-42.

Harrison-Walker, L. J. (2001). The measurement of word-of-mouth communication and an investigation of service quality and customer commitment as potential antecedents. Journal of service research, 4(1), 60-75.

Hasan, H. F. A., Ilias, A., Rahman, R. A., Razak, M. Z. A. (2009). Service quality and student satisfaction: A case study at private higher education institutions. International Business Research, 1(3), 163.

Haywood, K. M. (1989). Managing word of mouth communications. Journal of Services Marketing, 3(2), 55-67.

Helgesen, $\varnothing$., Nesset, E. (2007). Images, satisfaction and antecedents: Drivers of student loyalty? A case study of a Norwegian university college. Corporate Reputation Review, 10(1), 38-59.

Helgesen, $\varnothing$., Nesset, E. (2007). What accounts for students' loyalty? Some field study evidence. International Journal of Educational Management, 21(2), 126-143.

Hill, F. M. (1995). Managing service quality in higher education: the role of the student as primary consumer. Quality assurance in education, 3(3), 10-21.

Jones, T. O., Sasser, W. E. (1995). Why satisfied customers defect. Harvard business review, 73(6), 88.

Kotler, P., Clarke, R. N. (1987). Marketing for Health Organization. Prentic-Hall Inc.

Lampert, S. I., Rosenberg, L. J. (1975). Word of mouth activity as information search: a reappraisal. Journal of the Academy of Marketing Science, 3(3-4), 337-354.

Landrum, H., Prybutok, V. R., Zhang, X. (2007). A comparison of Magal's service quality instrument with SERVPERF. Information \& Management, 44(1), 104-113.

Lau, G. T., Ng, S. (2001). Individual and situational factors influencing negative word-of-mouth behaviour. Canadian Journal of Administrative Sciences/Revue Canadienne des Sciences de l'Administration, 18(3), 163-178. 
Li, S. C. (2013). Explore the Relationships among Service Quality, Customer Loyalty and Word-Of-Mouth for Private Higher Education in Taiwan. Asia Pacific Management Review.

Lissitz, R. W., Green, S. B. (1975). Effect of the number of scale points on reliability: A Monte Carlo approach. Journal of Applied Psychology, 60(1), 10.

Maru File, K., Cermak, D. S., Alan Prince, R. (1994). Word-of-mouth effects in professional services buyer behaviour. Service Industries Journal, 14(3), 301-314.

Marzo Navarro, M., Pedraja Iglesias, M., Rivera Torres, P. (2005). A new management element for universities: satisfaction with the offered courses. International Journal of educational management, 19(6), 505-526.

Matell, M. S., Jacoby, J. (1972). Is there an optimal number of alternatives for Likert-scale items? Effects of testing time and scale properties. Journal of Applied Psychology, 56(6), 506.

Mavondo, F., Zaman, M., Abubakar, B. (2000). Student satisfaction with tertiary institution and recommending it to prospective students. Proceedings of the Australia New Zealand Marketing Academy, 787-792.

McDougall, G. H., Levesque, T. (2000). Customer satisfaction with services: putting perceived value into the equation. Journal of services marketing, 14(5), 392-410.

O’Neil, M., Palmer, A. (2004). Importance-performance analysis: a useful tool for directing continuous quality improvements in higher education. Quality Assurance in Education, 12(1), 39-52.

Oliver, R. L. (1999). Whence consumer loyalty?. the Journal of Marketing, 33-44.

Oliver, R. L., Swan, J. E. (1989). Consumer perceptions of interpersonal equity and satisfaction in transactions: a field survey approach. The Journal of Marketing, 21-35.

Parasuraman, A., Berry, L. L., Zeithaml, V. A. (1991). Understanding customer expectations of service. Sloan management review, 32(3), 3948.

Parasuraman, A., Zeithaml, V. A., Berry, L. L. (1985). A conceptual model of service quality and its implications for future research. the Journal of Marketing, 41-50.

Parasuraman, A., Zeithaml, V. A., Berry, L. L. (1988). Servqual: A multiple-item scale for measuring consumer perc. Journal of retailing, 64(1), 12

Parasuraman, A., Zeithaml, V. A., Berry, L. L. (1994). Reassessment of expectations as a comparison standard in measuring service quality: implications for further research. the Journal of Marketing, 111-124.

Patti, C. H., Chen, C. H. (2009). Types of word-of-mouth messages: Information search and credence-based services. Journal of Promotion Management, 15(3), 357-381.

Ranaweera, C., Prabhu, J. (2003). The influence of satisfaction, trust and switching barriers on customer retention in a continuous purchasing setting. International journal of service industry management, 14(4), 374-395.

Reichheld, F. F., Sasser, J. W. (1990). Zero defections: Quality comes to services. Harvard bu

Richins, M. L. (1983). Negative word-of-mouth by dissatisfied consumers: A pilot study. The journal of marketing, 68-78.

Rowley, J. (1996). Measuring quality in higher education. Quality in Higher Education, 2(3), 237-255.

Sandhu, H. S., Bala, N. (2011). Customers' perception towards service quality of Life Insurance Corporation of India: A factor analytic approach. International Journal of Business and Social Science, 2(18), 219-231.

Shostack, G. L. (1977). Breaking free from product marketing. The Journal of Marketing, 73-80.

Smoldt, R. K. (1998). Turn word of mouth into a marketing advantage. In The Healthcare Forum Journal (Vol. 41, No. 5, pp. 47-49).

Soutar, G., McNeil, M. (1996). Measuring service quality in a tertiary institution. Journal of Educational Administration, 34(1), 72-82.

Sundaram, D. S., Mitra, K., Webster, C. (1998). Word-of-mouth communications: A motivational analysis. ACR North American Advances.

Vagias, W. M. (2006). Likert-type Scale Response Anchors. Clemson International Institute for Tourism. \& Research Development, Department of Parks, Recreation and Tourism Management, Clemson University.

Van Damme, D. (2001). Quality issues in the internationalisation of higher education. Higher education, 41(4), 415-441.

Van Dolen, W. M., Dabholkar, P. A., De Ruyter, K. (2007). Satisfaction with online commercial group chat: the influence of perceived technology attributes, chat group characteristics, and advisor communication style. Journal of retailing, 83(3), 339-358.

Wirtz, J., Chew, P. (2002). The effects of incentives, deal proneness, satisfaction and tie strength on word-of-mouth behaviour. International journal of service industry management, 13(2), 141-162. 
Zammuto, R. F., Keaveney, S. M., O'Connor, E. J. (1996). Rethinking student services: assessing and improving service quality. Journal of Marketing for Higher Education, 7(1), 45-70.

\section{APPENDIX}

Questionnaire

Respondent's Detail:

\begin{tabular}{|c|c|c|c|}
\hline AGE & & & \\
\hline 20 and below & $26-30$ & $31-35$ & $36 \&$ above \\
\hline \multicolumn{4}{|l|}{ GENDER } \\
\hline Male & Female & & \\
\hline \multicolumn{4}{|l|}{ DEGREE PROGRAMME } \\
\hline Bachelor & Master & & Doctoral \\
\hline \multicolumn{4}{|l|}{ FACULTY } \\
\hline Communication and Media Studies & Arts and Sciences & \multicolumn{2}{|c|}{ Business and Economic } \\
\hline Health Sciences & Education & \multicolumn{2}{|c|}{ Engineering } \\
\hline Architecture & Law & \multicolumn{2}{|c|}{ Medicine } \\
\hline Pharmacy & \multicolumn{3}{|c|}{ Tourism } \\
\hline
\end{tabular}


Iranian Students' satisfaction towards the Service Quality in Eastern Mediterranean university of North Cyprus

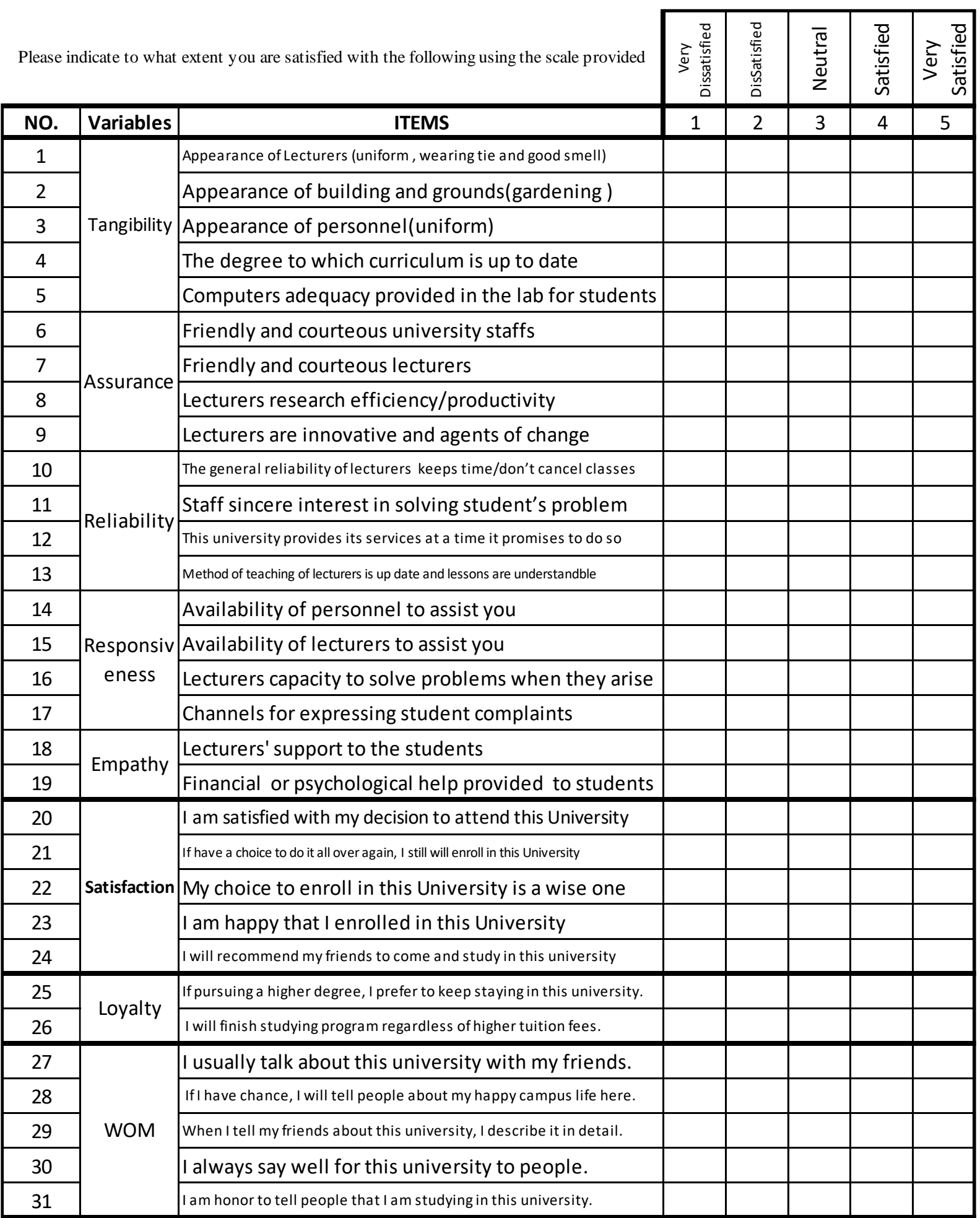

